\title{
The Influence of Instagram Travel Influencers and Travel Motivation on Destination Image and Travel Intention
}

\author{
Khadeeja Bilquees A., Deepa Ittimani Tholath
}

\begin{abstract}
This paper examines the ties between the variables Instagram Travel Influencers and Travel Motivation on Travel intention. This study was conducted at India International Travel Mart at Bangalore. A sample of 150 respondents who had followed Travel influencers on Instagram were interviewed and their responses noted and analyzed. Destination Image was considered to be the mediator. The results are elucidated. Instagram Travel Influencers have a profound effect on the Travel Intention directly as well as with having Destination Image as the mediating variable.
\end{abstract}

Keywords : Instagram Travel Influencers, Travel Motivation, Travel Intention and Destination Image.

\section{INTRODUCTION}

The travel conscious Indian traveler has now come off age and is definitely influenced by advancements in media especially Social Media and seeks out at newer horizons before the travel plan is made. Travelers do have a good view of Instagram, Facebook and other such platforms before making the plunge to seek travel pleasure.

As far as travel is concerned people always want to know what is in store for them. So they prefer to watch videos and pictures of the Destination they intend to travel. Instagram is the ideal Social Media tool used by many before making travel plans.Instagram users blog and update their travel experiences constantly and a few eventually end up in becoming travel influencers who can influence an individual to go travelling.

There are very few studies which try to understand how Instagram Travel Influencers are used to affect Travel Intention. Here in this study it is used in parallel with the Motivation to travel with Destination Image being the mediating variable.

\section{LITERATURE REVIEW}

It was 2010 when Instagram came into existence in and it has grown by leaps and bounds. Instagram is a novel photo and video sharing networking platform which can be

Revised Manuscript Received on December 05, 2019.

* Correspondence Author

Khadeeja Bilquees A.*, Research Scholar, Loyola Institute of Business Administration, Chennai, India. E-mail id: justkads@gmail.com

Dr. Deepa Ittimani Tholath, Associate Professor and Research Supervisor, Loyola Institute of Business Administration, Chennai, India. E-mail id: deepa.ittimani@liba.edu. accessed both from the mobile and the computer but predominantly an increasing number of people use it more on the mobile phone.The significance of this platform is that it is a "self-promotion aid" and it encourages interaction among its users. (MegasariNoerFatanti2015).

Instagram has given rise to Travel influencers who are just audiences who indirectly become a part of the promotion agent of tourism destination through their photography.

The latest buzz in the Social media world is Influencer Marketing. It was Gillin (2007) who stated that there a new interactive way to advertise products to the world market and that was via influencer marketing on social media.

Motivation is a driving force which demonstrates diverse behaviors towards certain kinds of activities, evolving preferences to reach certain gratifying outcomes.(Backman et al., 1995, p. 17).Much research has been done to comprehend the motivation for people to engage in travel to different destinations.One of the relevant definitions of Travel Motivation indicates that it is an emotional state which sufficiently pushes one to travel and gives some logical explanation for the decision. Dann (1981, p. 3)

Destination Image is believed to be a significant mediator between travel intentions, information sources used and travel motivation (Crompton, 1979; Baloglu,2000; Jang, Bai, $\mathrm{Hu} \& \mathrm{Wu}, 2009)$.Different information sources create different perceptions of Destination Image and it is formed by the gradual culmination of various sources of influences on the person's mind.(Court \& Lupton, 1997).

\section{CONCEPTUAL FRAMEWORK}

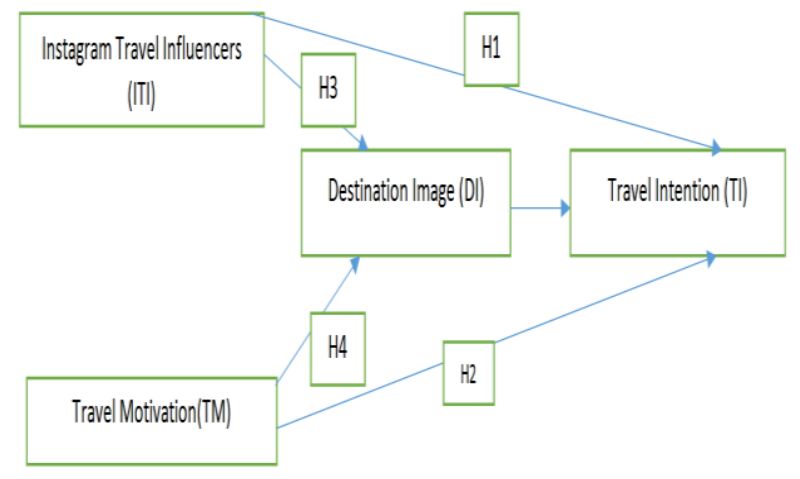

Figure - 1: Conceptual Framework 


\begin{tabular}{|c|c|c|c|}
\hline ITI & .167 & 0.000 & H1 Accepted \\
\hline TM & .286 & 0.000 & H2 Accepted \\
\hline & & & \\
\hline
\end{tabular}

\section{A. Hypothesis}

H1: Instagram Travel Influencers (ITI)have an effect on travel intention.

H2: Travel motivation(TM)have an effect on travel intention

H3: Destination image (DI)acts as the mediator between Instagram Travel Influencers and Travel intention.

H4: Destination image acts as the mediator between Travel motivation and travel intention

\section{METHODOLOGY}

The travel exhibition at Bengaluru was an event with a view to promote travel. This event had many visitors who were looking forward to make travel plans. This study was conducted at India International Travel Mart at Bangalore.The target sample was exposed to the travel influencers on Instagram who were promoting the sought after destination image at the particular stall. The age group of the respondents was purposely chosen between 18 to 45 as they had a higher probability of being aware of social media influencers. Thequestionnaire was distributed to many but the final shortlisted sample consisted of 150 respondents' answers. A questionnaire was employed to measure the research framework variable constructs. Instagram Travel Influencers, travel motivation, destination image, and travel intention were the major variables measured with suitable items on a well defined scale.

\section{RESULTS AND DISCUSSION}

\section{A. Descriptive Statistics}

Table - 1: Demographic Profile

\begin{tabular}{|c|c|}
\hline Characteristics & Percent \\
\hline Gender & \\
\hline Male & 29 \\
\hline Female & 71 \\
\hline Age & \\
\hline 18-24 years & 45 \\
\hline 25-34 years & 40 \\
\hline 35-45 years & 15 \\
\hline Annual Income & \\
\hline$<5$ lakhs & 28 \\
\hline 5-10 lakhs & 34 \\
\hline 10-15 lakhs & 14 \\
\hline$>15$ lakhs & 24 \\
\hline
\end{tabular}

Table -2 the demographic view of the population is displayed above.

Table - 2: Bivariate Pearson's Correlation

\begin{tabular}{|l|c|c|c|}
\hline & \multicolumn{2}{|c|}{$\begin{array}{c}\text { Travel Intention } \\
\text { (TI) }\end{array}$} & $\begin{array}{c}\text { Result of } \\
\text { Hypothesis }\end{array}$ \\
\hline & $\begin{array}{c}\text { Pearson } \\
\text { Correlation }\end{array}$ & Sig. (2-tailed) & \\
\hline
\end{tabular}

Table 2 Bivariate Pearson's Correlation

The results elucidated here indicate that travel intention is profoundly affected by ITI, travel motivation, and destination image. Bivariate Pearson Correlation was used to investigate the legitimacy of hypothesis 1 and 2.The values are tabulated in the table above. The results indicate that Correlation was found to be significant at the 0.01 level and hence that hypothesis 1 and 2 can be endorsed to be true.

Multivariate Analysis technique of Regression was employed to test the direct and indirect effect between the endogenous and exogenous variables. $\mathrm{B}=\beta 0+\beta 1 \quad \mathrm{~A}+\beta 2$ $M+e$ Hypothesis 3 and 4 are tested based on Regression Analysis.A in the equation is independent variables (Instagram Travel Influencers and travel motivation), B is dependent variable (travel intention), and $\mathrm{M}$ is mediating factor (destination image).The technique used was of Baron and Kenny's (1986) four steps approach.

Path analysis was also employed to understand the mediating effect between the variables.

Destination image was found to mediate the relationship between Instagram Travel Influencersand travel intention, supporting Hypothesis 3.

Destination Image however has no mediation effect on Travel Motivation and Travel Intention as demonstrated by Table 4.4.However when destination image is controlled the

Value of travel motivation is still existing and significant $(\mathrm{p}<0.05)$.

Hypothesis 4 was rejected as Destination image did notmediate the relationship between the variables travel motivation and travel intention.

Table -3

\begin{tabular}{|c|c|c|c|c|c|}
\hline \multirow{2}{*}{$\begin{array}{l}\text { Predictor } \\
\text { variable }\end{array}$} & \multirow{2}{*}{$\begin{array}{c}\text { Dependent } \\
\text { Variable }\end{array}$} & \multicolumn{2}{|c|}{$\begin{array}{c}\text { Raw Coefficients } \\
\text { Unstandardized }\end{array}$} & $\begin{array}{l}\text { Standardized } \\
\text { Coefficients }\end{array}$ & $\mathrm{t}$-Value \\
\hline & & $\mathrm{B}$ & Std. Err & Beta weights & \\
\hline ITI(constant) & TI & $\begin{array}{c}10.116 \\
0.136 \\
0.472\end{array}$ & $\begin{array}{c}0.462 \\
.038\end{array}$ & 0.168 & $\begin{array}{c}22.873 \\
3.491\end{array}$ \\
\hline $\mathrm{DI}$ (constant) & TI & $\begin{array}{l}5.200 \\
0.144\end{array}$ & $\begin{array}{l}0.723 \\
0.014\end{array}$ & 0.427 & $\begin{array}{c}7.428 \\
10.627\end{array}$ \\
\hline ITI( constant) & DI & $\begin{array}{c}40.443 \\
0.463 \\
\end{array}$ & $\begin{array}{l}1.327 \\
0.116 \\
\end{array}$ & 0.221 & $\begin{array}{c}28.478 \\
4.436 \\
\end{array}$ \\
\hline $\begin{array}{l}\text { DI(constant) } \\
\text { ITI(constant) }\end{array}$ & TI & $\begin{array}{l}4.836 \\
0.157 \\
0.059\end{array}$ & $\begin{array}{l}0.759 \\
0.016 \\
0.035\end{array}$ & $\begin{array}{r}0.450 \\
0.075\end{array}$ & $\begin{array}{l}6.286 \\
9.185 \\
1.607\end{array}$ \\
\hline
\end{tabular}

Table 3 Outcome of the Relationship between Instagram Travel Influencers, Destination image, and Travel intention using Regression

Table -4

\begin{tabular}{|c|c|c|c|c|c|}
\hline \multirow[t]{2}{*}{ Predictor variable } & \multirow{2}{*}{$\begin{array}{c}\text { Dependent } \\
\text { Variable }\end{array}$} & \multicolumn{2}{|c|}{$\begin{array}{c}\text { Raw Coefficients } \\
\text { Unstandardized }\end{array}$} & $\begin{array}{l}\text { Standardized } \\
\text { Coefficients }\end{array}$ & \multirow[t]{2}{*}{$\mathrm{t}$} \\
\hline & & $\mathrm{B}$ & Std. Err & Beta weights & \\
\hline $\mathrm{TM}$ (constant) & TI & $\begin{array}{l}6.513 \\
0.158\end{array}$ & $\begin{array}{l}0.842 \\
0.023\end{array}$ & 0.307 & $\begin{array}{l}8.804 \\
6.585\end{array}$ \\
\hline DI(constant) & TI & $\begin{array}{l}6.300 \\
0.162 \\
\end{array}$ & $\begin{array}{l}0.613 \\
0.014 \\
\end{array}$ & 0.457 & $\begin{array}{l}7.227 \\
10.88 \\
\end{array}$ \\
\hline TM(constant) & DI & $\begin{array}{c}32.436 \\
0.218 \\
\end{array}$ & $\begin{array}{l}2.479 \\
0.068 \\
\end{array}$ & 0.155 & $\begin{array}{r}15.402 \\
2.199 \\
\end{array}$ \\
\hline
\end{tabular}




\begin{tabular}{|c|c|c|c|c|c|}
\hline $\begin{array}{l}\text { DI(constant) } \\
\text { ITI(constant) }\end{array}$ & TI & $\begin{array}{l}1.594 \\
0.121 \\
0.120\end{array}$ & $\begin{array}{l}0.847 \\
0.015 \\
0.021\end{array}$ & $\begin{array}{l}0.330 \\
0.240\end{array}$ & $\begin{array}{l}1.683 \\
9.170 \\
4.688\end{array}$ \\
\hline
\end{tabular}

Table 4 Outcome of the Relationship between Travel motivation, destination image, and travel intention using Regression

\section{DISCUSSION AND FINDINGS}

In this study it is found that the ITI has significant effect on Travel Intention both directly as well as when Destination Image is the mediating variable. However we also note that the Travel motivation also has an effect on Travel Intention. However the mediation of Destination Image with respect to the Travel Motivation is not significant. This study will be helpful to marketers to understand how they can use Instagram Travel Influencers with specific Destination Image promotion to promote travel to the prescribed destination.

\section{CONCLUSION}

The relationship between the Instagram Travel Influencers and Motivation for Travel was not analyzed here and that can also form a part of future research. The sample population was limited to the ones at the exhibition and may be biased and the results cannot be generalized.

\section{REFERENCES}

1. Fatanti, M. N., \&Suyadnya, I. W. (2015). Beyond User Gaze: How Instagram Creates Tourism Destination Brand? Procedia - Social and Behavioral Sciences, 211, 1089-1095. https://doi.org/10.1016/j.sbspro.2015.11.145

2. Baloglu, S. (2000). A path analytic model of visitation intention involving information sources, socio-psychological motivations, and destination image. Journal of Travel \& tourism Marketing, 8(3), 81-90. Baloglu, S.,

3. Backman, K. F., Backman, S. J., Uysal, M., \& Sunshine, K. M. (1995). Event tourism: an examination of motivations and activities. Festival Management \& Event Tourism, 3 (1), 15-24.

4. Dann, G. M. (1981). Tourism Motivations: An appraisal. Annals of Tourism Research, 8(2), 189-219.

5. Crompton, J. L. (1979). Motivations of pleasure vacation. Annals of Tourism Research, 6, 408-424. Cutler, S. Q., \& Carmichael, B. A. (2010). The dimensions of the tourist experience. The tourism and leisure experience: Consumer and managerial perspectives, 3-26

6. Baron, R. M., \& Kenny, D. A. (1986). The moderator-mediator variable distinction in social psychological research: Conceptual, strategic, and statistical considerations. Journal of Personality and Social Psychology, 51(6), 1173

7. Jang, S., Bai, B., Hu, C., \& Wu, C. M. E. (2009). Affect, travel motivation, and travel intention: A senior market. Journal of Hospitality \& Tourism Research, 33(1), 51-73.

8. Court, B., \& Lupton, R. A. (1997). Customer portfolio development: Modeling destination adopters, inactives, and rejecters. Journal of Travel Research, 36(1), 35-43.

\section{AUTHORS PROFILE}

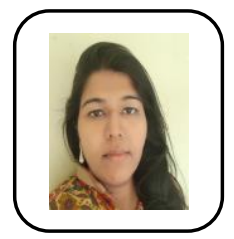

Khadeeja Bilquees A., is a research scholar at LIBA( Loyola Institute of Business Administration) Her research is predominantly in the field of Social Media Marketing-Influencer Marketing to be precise. She has completed her Bachelors in ECE( Electronics and Communication Engineering) along with an MBA (Information Systems)followed by an M.Phil. (Management). She also is brilliant in academics. She has had a work experience close to 6 years and has published several papers on Influencer
Marketing in several national peer- reviewed journals and presented papers at national and international conferences.

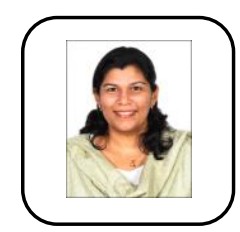

Dr. Deepa Ittimani Tholath, is an Associate Professor of Marketing Management at LIBA. she is a university gold medalist at the MBA level. Her doctoral thesis is on knowledge management and its implementation possibilities in the service sector. She began her career as a banker at IDBI bank and later shifted to teaching by introducing knowledge management as an elective at LIBA in 2001. Her research interests include consumer behaviour, pricing, knowledge management, influencer marketing and services marketing. She has published papers in national peer- reviewed journals and presented papers at national and international conferences. She is a research guide registered with the University of Madras. 